\title{
FITOREMEDIASI TANAH TERCEMAR LOGAM BERAT Cd MENGGUNAKAN TANAMAN HANJUANG (Cordyline fruticosa)
}

\author{
Novie Eka Permata Sari, Nurlela*, Supriyono Eko Wardoyo \\ Program Studi Kimia, Fakultas MIPA, Universitas Nusa Bangsa Bogor \\ Jl. KH. Sholeh Iskandar Km 4, Cibadak, Kec, Tanah Sareal, Kota Bogor, Kode Pos 16166 \\ *email: nnurlela16@gmail.com
}

\author{
ABSTRACT \\ Phytoremediationn of Cadmium (Cd) Contaminated Soil using Hanjuang Plants \\ (Cordyline fruticosa)
}

\begin{abstract}
Phytoremediation of Cadmium (Cd) contaminated soil using ornamental plants is one method that applicable and environmental friendly in the process absorption of metal in the soil. This study aims to determine the effectiveness of phytoremediation and the potential of hanjuang plants as phytoremediation agents for cadmium metals. The type of plant used in this research are Hanjuang plants. Hanjuang plants are planted on soil media which is previously added to heavy media as pollutants, namely $\mathrm{Cd}\left(\mathrm{NO}_{3}\right)_{2}$ with a concentration of $0 ; 50 ; 100 ; 150 \mathrm{mg} / \mathrm{Kg}$ for 42 days. Measurement of Cd concentration uses Inductively Coupled Plasma Optical Emission Spectrometry instrument. The data obtained were processed statistically by One Way Analysis of Variance and further test Honestly Significant Difference (HSD). The results showed that hanjuang plants could accumulate cadmium metals in the roots. The highest accumulation is found in the roots of plants at $150 \mathrm{mg} / \mathrm{Kg}$ concentration and the result is $36.2167 \mathrm{mg} / \mathrm{Kg}$, whereas in the stems and leaves of plants is not found heavy metal absorptions. Hanjuang plants contaminated with cadmium metal have a bioconcentration value $(B C F)<1$ so that they are included in the metal excluder group or low accumulator. The highest distribution of cadmium metal concentration is in the roots with transport factor $(T F)<1$ so that hanjuang plants are included in phytoremediation plants with their metal absorption which mechanism is phytostabilization.
\end{abstract}

Keywords: Cordyline fruticosa, Phytoremediation, Cadmium, ICP-OES

\begin{abstract}
ABSTRAK
Fitoremediasi tanah tercemar logam Kadmium (Cd) menggunakan tanaman hias merupakan salah satu metode yang aplikatif dan ramah lingkungan dalam proses penyerapan logam di dalam tanah. Penelitian ini bertujuan untuk mengetahui efektivitas fitoremediasi dan potensi tanaman hanjuang sebagai agen fitoremediasi dalam menyerap logam kadmium. Jenis tanaman yang digunakan dalam penelitian ini adalah tanaman hanjuang (Cordyline fruticosa). Tanaman hanjuang ditanam pada media tanah yang sebelumnya media tanah tersebut ditambahkan logam berat sebagai pencemar yaitu $\mathrm{Cd}\left(\mathrm{NO}_{3}\right)_{2}$ dengan variasi konsentrasi $0 ; 50 ; 100 ; 150 \mathrm{mg} / \mathrm{Kg}$ selama 42 hari. Pengukuran konsentrasi $\mathrm{Cd}$ menggunakan instrumen Inductively Coupled Plasma - Optical Emission Spectrometry. Data yang diperoleh diolah secara statistik dengan Analisis Varian satu faktor (ANOVA) dan uji lanjut Beda Nyata Jujur (BNJ/Tukey). Hasil penelitian menunjukkan tanaman hanjuang dapat mengakumulasi logam kadmium pada bagian akar. Akumulasi tertinggi ditemukan pada bagian akar tanaman pada konsentrasi $150 \mathrm{mg} / \mathrm{Kg}$ sebesar 36,2167 mg/Kg, sedangkan pada bagian batang maupun daun tanaman tidak ditemukan adanya penyerapan. Tanaman hanjuang yang terkontaminasi oleh logam kadmium memiliki nilai biokonsentrasi (BCF) $<1$ sehingga termasuk ke dalam kelompok metal excluder atau akumulator rendah. Distribusi konsentrasi logam kadmium paling tinggi terdapat pada bagian akar dengan faktor transport (TF) $<1$ sehingga tanaman Hanjuang termasuk ke dalam tanaman fitoremediasi dengan mekanisme penyerapan logamnya yaitu fitostabilisasi.
\end{abstract}

Kata kunci: Cordyline fruticosa, Fitoremediasi, Kadmium, ICP-OES. 


\section{PENDAHULUAN}

Sektor industri menempati poros utama dalam pembangunan ekonomi serta peningkatan kemakmuran di berbagai negara terutama negara berkembang. Meningkatnya pembangunan dan penggunaan bahan baku logam pada sektor industri, memicu dampak negatif yaitu semakin banyaknya pencemaran pada lingkungan. Limbah yang dihasilkan pada proses industri mengandung logam berat seperti timbal $(\mathrm{Pb})$, krom $(\mathrm{Cr})$, tembaga $(\mathrm{Cu})$, seng $(\mathrm{Zn})$, kadmium $(\mathrm{Cd})$ dan merkuri (Hg) (Fardiaz, 2008).

Kadmium (Cd) merupakan logam berat yang bersifat toksik tinggi. Logam kadmium bersifat karsinogenik. Karsinogenik merupakan zat yang dapat menyebabkan kanker. Kanker merupakan suatu penyakit yang disebabkan oleh kerusakan gen, materi genetik atau DNA sel (Widowati et al., 2008). Kadmium umumnya dapat ditemukan pada tanah dan air dalam kadar rendah. Sumber kadmium dapat diperoleh dari sumber alami (gunung berapi), pertambangan maupun industri (bahan ikutan dari pengolahan dan produksi $\mathrm{Pb}, \mathrm{Zn}, \mathrm{Cu}$, minyak serta batu bara) (Dewi, 2010).

Salah satu metode yang aplikatif dan diharapkan mampu menangani masalah pencemaran logam berat pada tanah adalah fitoremediasi (Schanoor dan Cutcheon, 2003 dalam Haryanti et al., 2013). Fitoremediasi juga sering disebut sebagai bioremediasi botani (Chaney et al., 1997 dalam Pratiwi, 2017).

Fitoremediasi adalah salah satu upaya untuk mengurangi kerusakan tanah akibat tingginya akumulasi logam berat dengan memanfaatkan tanaman yang dapat menyerap logam berat (Wulandari et al., 2014). Dengan demikian, fitoremediasi juga dapat berarti pemanfaatan tumbuhan untuk meminimalisasi dan mendetoksifikasi bahan pencemar, karena tanaman mempunyai kemampuan menyerap logam-logam berat dan mineral yang tinggi atau sebagai fitoakumulator (Udiharto, 1992).

Pada penelitian ini, tanaman yang akan dimanfaatkan untuk proses fitoremediasi adalah tanaman hanjuang (Cordyline fruticosa). Pemilihan tanaman hanjuang sebagai agen fitoremediator pada penelitian ini didasarkan pada pertimbangan bahwa tanaman tersebut memiliki volume akar yang banyak (Haryanti et al., 2013). Akar merupakan organ tanaman yang berfungsi menyerap unsur hara dari media tanah dan sekaligus organ yang kontak langsung dengan media tanam dan sebagian besar unsur yang dibutuhkan tanaman diserap dari tanaman melalui akar (Dahlan, 2004 dalam Haryanti et al., 2013)

Menurut Raskin et al (1999), fitoremediasi adalah salah satu cara untuk memulihkan lingkungan tanah dari suatu kontaminan logam berat dengan menggunakan tanaman, yaitu dengan cara menanam jenis-jenis tanaman yang mampu menyerap logam berat dari dalam tanah. Tumbuhan yang memiliki kemampuan untuk menyerap logam berat dari tanah dikenal sebagai tumbuhan hiperakumulator (Hardiani, 2009 dalam Yusuf, 2014). Karakteristik tumbuhan hiperakumulator adalah tahan terhadap unsur logam dalam konsentrasi tinggi pada jaringan akar dan tajuk, tingkat laju penyerapan unsur dari tanah yang tinggi dibanding tanaman lain, dan memiliki kemampuan mentranslokasi dan mengakumulasi unsur logam dari akar ke tajuk dengan laju yang tinggi (Brown et al., 1995 dalam Hidayati, 2005).

Faktor-faktor yang mempengaruhi keberhasilan fitoremediasi yaitu kemampuan daya akumulasi berbagai jenis tanaman untuk berbagai jenis polutan dan konsentrasi, sifat kimia dan fisika, serta sifat fisiologi tanaman, jumlah zat kimia berbahaya, mekanisme akumulasi dan hiperakumulasi ditinjau secara fisiologi, biokimia, dan molekular, serta penggunaan konsentrasi limbah yang tepat sangat menentukan keberhasilan pada proses fitoremediasi (Estuningsih et al., 2013)

Menurut penelitian Haryanti et al (2013) tanaman hanjuang memiliki kemampuan dan potensi yang baik dalam meremediasi logam timbal dalam tanah. Tanaman hanjuang diketahui dapat menyerap logam timbal sebesar 141,56 $\mathrm{mg} / \mathrm{kg}$ dengan efisiensi penyerapan logam timbal sebesar 44,28\%. Sedangkan untuk penyerapan logam kadmium oleh tanaman hanjuang belum banyak diungkap. Oleh karena itu, dilakukan penanaman tanaman 
hanjuang sebagai agen fitoremediator untuk mengetahui efektivitas dan potensi tanaman tersebut dalam penyerapan logam kadmium. Ketersediaan unsur logam dan penyerapannya oleh tanaman ditentukan oleh konsentrasi total dan bentuk dari logam tersebut di dalam tanah selain faktor geokimia pada zona perakaran. Faktor genetik dan jenis tumbuhan menentukan penyerapan logam pada zona perakaran dan akar / tajuk pada tingkat yang bervariasi. Penyerapan juga ditentukan oleh tipe jaringan tanaman dan perlakuan yang diberikan pada tanah (Knox et al., 2000; Vangronsveld et al., 2000 dalam Hidayati, 2005).

Konsentrasi optimum tanaman hanjuang yang toleran terhadap logam kadmium dapat diketahui dengan menambahkan logam kadmium pada media tanah dengan berbagai konsentrasi dan variasi waktu tertentu. Kandungan logam kadmium yang terserap oleh tanaman hanjuang dapat diukur dengan menggunakan Inductively Coupled Plasma (ICP).

\section{BAHAN DAN METODE}

\section{Bahan dan Alat}

Bahan-bahan yang digunakan adalah tanaman hanjuang, akuades, $\mathrm{HNO}_{3} 65 \%$, $\mathrm{HClO}_{4} 70 \%, \mathrm{HNO}_{3}$ 0,5 $\mathrm{M}$ dan hablur $\mathrm{Cd}\left(\mathrm{NO}_{3}\right)_{2} \cdot 4 \mathrm{H}_{2} \mathrm{O}$. Peralatan yang digunakan dalam penelitian ini yaitu, neraca analitik, oven, kertas saring, hotplate, labu ukur, lemari asam, gelas ukur, gelas piala, pipet ukur, corong kaca, bulb, polybag, lumpang, alu, spatula, wadah plastik, dan Inductively Coupled Plasma Optical Emission Spectrometry (ICP-OES).

\section{Metode \\ Penyiapan Media Tanah}

Tanah yang digunakan dalam penelitian ini diambil dari Rumah Kaca Universitas Nusa Bangsa Bogor. Tanah tersebut dibersihkan dari batuan dan akar-akaran yang ada. Sebelum proses fitoremediasi tanah tercemar logam berat dilakukan, terlebih dahulu dilakukan analisis pada media tanah yang digunakan untuk mengetahui kandungan awal logam pada media tanah tersebut.

\section{Penanaman Tanaman Hanjuang}

Tanaman hanjuang yang digunakan dalam penelitian diambil dengan keseragaman tinggi dan ukuran yang sama. Tanaman yang telah disiapkan lalu dimasukkan ke dalam polybag. Pembibitan tanaman menggunakan metode stek.

\section{Pembuatan Sampel Tanah Terkonta-minasi logam $C d$}

Konsentrasi yang diinginkan dalam penelitian ini terlebih dahulu ditentukan. Konsentrasi ion $\mathrm{Cd}(\mathrm{II})$ yang digunakan adalah 0, 50, 100 dan $150 \mathrm{mg} / \mathrm{Kg}$.

\section{Pengamatan}

Tanaman yang telah ditanam pada polybag diamati selama 42 hari. Setelah 42 hari tanaman dipanen, sampel tanaman tersebut dipisahkan antara bagian akar, batang dan daunnya kemudian dikemas serta diberi label pengkodean sesuai dengan konsentrasi pencemar logam berat yang ditambahkan. Sampel siap di preparasi dan dilakukan pengukuran logam kadmium dengan menggunakan Inductively Coupled Plasma (ICP). Analisis kadar kadmium dalam tanah berdasarkan SNI 06-6992.42004.

\section{Analisis Data \\ Biomassa Kering (Indriyana, 2014)}

Sampel tanaman yang ditanam di dalam media tanah tercemar dipanen setelah 42 hari. Tanaman dipanen beserta akarnya, kemudian dicuci bersih. Tanaman dipisahkan bagian akar, batang dan daun. Sampel akar, batang dan daun masing-masing ditimbang berat basah, kemudian dikeringkan di dalam oven pada suhu $70{ }^{\circ} \mathrm{C}$ selama 3 hari. Lalu dimasukkan ke dalam desikator selama 20 30 menit, selanjutnya ditimbang berat kering. Berat kering inilah disebut nilai biomassa.

\section{Analisis Kandungan Kadmium pada Tanah (SNI 06-6992.4-2004)}

Media tanah ditimbang dengan teliti sebanyak $3 \mathrm{~g}$ dan dimasukkan ke dalam piala gelas $100 \mathrm{~mL}$. Kemudian ditambahkan 10 - 
$15 \mathrm{~mL} \mathrm{HNO}_{3} 65 \%$. Kemudian sampel dipanaskan di atas pemanas listrik dengan suhu $105-120{ }^{\circ} \mathrm{C}$, kemudian diangkat dan dinginkan. Setelah dingin, ditambahkan lagi $\mathrm{HNO}_{3} 65 \%$ dan $\mathrm{HClO}_{4} 70 \%$, kemudian dipanaskan kembali sampai timbul asap putih dan larutan uji menjadi jernih. Setelah timbul asap putih, pemanasan dilanjutkan selama 30 menit. Contoh uji yang sudah dingin, kemudian disaring dengan kertas saring, kemudian filtratnya ditempatkan pada labu ukur $50 \mathrm{~mL}$ dan ditambahkan akuades sampai tanda tera. Filtrat sampel uji diukur dengan menggunakan alat Inductively Coupled Plasma Optical Emission Spectrometry (ICP-OES).

\section{Analisis Kandungan Logam pada Contoh Uji Tanaman (SNI 06-698945 Tahun 2005)}

Contoh uji tanaman ditimbang dengan teliti sebanyak $3 \mathrm{~g}$, kemudian dimasukkan ke dalam piala gelas $100 \mathrm{~mL}$. Selanjutnya ditambahkan $10-15 \mathrm{~mL} \mathrm{HNO}_{3} 65 \%$. Kemudian sampel dipanaskan di atas pemanas listrik dengan suhu $105-120{ }^{\circ} \mathrm{C}$, kemudian diangkat dan didinginkan. Setelah dingin, ditambahkan lagi $\mathrm{HNO}_{3} 65 \%$ dan $\mathrm{HClO}_{4} 70 \%$. Contoh uji dipanaskan kembali dan dibiarkan menguap hingga volume larutan sedikit. Selanjutnya, larutan contoh uji dipindahkan ke dalam labu ukur $50 \mathrm{~mL}$ dan ditambahkan akuades sampai tanda tera. Filtrat contoh, selanjutnya diukur dengan menggunakan alat Inductively Coupled Plasma Optical Emission Spectrometry (ICP-OES).

\section{Karakter Serapan logam pada tanaman \\ a. Efisiensi Penyerapan}

Efisiensi penyerapan logam kadmium pada tanaman didasarkan pada konsentrasi logam kadmium dalam tanaman serta konsentrasi logam kadmium dalam media tanah (Haryanti et al., 2013).

Efisiensi Penyerapan $=$ $\frac{\text { Konsentrasi Logam berat pada tanaman }}{\text { Konsentrasi Logam berat pada tanah (awal) }} \times 100 \%$

\section{b. Faktor Transport}

Proses terjadinya translokasi perbandingan antara konsentrasi logam di tajuk dengan konsentrasi logam di akar pada tanaman ditentukan dengan nilai TF (Haque et al., 2008).

$T F=\frac{\text { Konsentrasi logam dalam tajuk tanaman }}{\text { Konsentrasi logam dalam akar tanaman }}$

\section{c. Faktor Biokonsentrasi}

Potensi tanaman dalam mengakumulasi logam kadmium pada tanah akan dianalisis dengan menghitung nilai biokonsentrasi (BCF) yang ditentukan oleh rasio logam di akar dengan yang terdapat di dalam tanah (Ghosh and Singh, 2013).

$B C F$

$=\frac{\text { Konsentrasi logam dalam akar tanaman }}{\text { Konsentrasi logam dalam tanah }}$

\section{d. Bioakumulasi}

Bioakumulasi dihitung dari konsentrasi logam pada akar dikalikan dengan berat kering akar dan dijumlahkan dengan hasil perkalian konsentrasi logam pada pucuk dengan berat kering pada pucuk (Sarma, 2011).

Bioakumulasi $=$

Konsentrasi logam tanaman $\left(\frac{\mathrm{mg}}{\mathrm{kg}}\right) \times$ Biomassa tanaman $(\mathrm{kg})$

\section{e. Potensi Remediasi}

Potensi Remediasi ditunjukkan dengan efektivitas tanaman dalam menyerap logam berat dalam tanah. Nilai tersebut dihitung berdasarkan efektivitas penyisihan dari logam yang terkandung didalam media tanah yang sudah ditanami tanaman hanjuang selama 42 hari (Yusuf, 2014).

Efektivitas Penyisihan (\%)

$=\frac{C \text { awal media }-C \text { akhir media }}{\text { Konsentrasi logam awal media }} \times 100 \%$

\section{f. Analisis Data Menggunakan Uji Statistik Metode One Way ANOVA}

Analisis Varians Satu Jalan (One Way Analysis of Variance) merupakan teknik analisis yang digunakan untuk menguji perbedaan rata-rata dengan banyak kelompok yang terpilih secara acak (Kadir, 2015). Konsep yang mendasari ANOVA adalah varians dari skor yang bertumpu pada dua buah sumber. Pertama varians antar kelompok yaitu varians yang disebabkan oleh perlakuan dan kedua varians dalam 
kelompok, yaitu varians yang disebabkan oleh kekeliruan pemilihan sampel (Ruseffendi, 1993 dalam Kadir, 2015).

Data hasil pengukuran yang diperoleh dianalisis menggunakan aplikasi SPSS 24 dengan uji One Way ANOVA metode Rancangan Acak Lengkap (RAL) yang terdiri dari empat variasi perlakuan dan tiga kali ulangan. Untuk mengetahui adanya perbedaan antar perlakuan, kemudian dilanjutkan dengan uji BNJ / Tukey dengan taraf nyata $\alpha=5 \%$.

\section{HASIL DAN PEMBAHASAN}

\section{Konsentrasi Logam pada Media Tanah}

Konsentrasi logam kadmium dalam media tanah pada awal penanaman hingga 42 hari penanaman, didapatkan penurunan konsentrasi pada media tanah. Penurunan konsentrasi logam dapat diakibatkan oleh beberapa proses, salah satunya adalah fitoremediasi logam oleh tanaman. Konsentrasi logam kadmium pada media tanah dapat dilihat pada Tabel 1 .

Tabel 1. Konsentrasi Logam Kadmium pada Media Tanah

\begin{tabular}{|c|c|c|}
\hline Perlakuan & $\begin{array}{c}\text { Media } \\
\text { Awal } \\
(\mathrm{mg} / \mathrm{Kg})\end{array}$ & $\begin{array}{c}\text { Media } \\
\text { Akhir } \\
\text { (mg/Kg) }\end{array}$ \\
\hline \multirow{3}{*}{$\begin{array}{l}\text { konsentrasi } \mathrm{Cd} 0 \mathrm{mg} / \mathrm{Kg} \\
\text { konsentrasi Cd } 50 \\
\mathrm{mg} / \mathrm{Kg} \\
\text { konsentrasi Cd } 100 \\
\mathrm{mg} / \mathrm{Kg}\end{array}$} & $0,00 \mathrm{a}$ & $0,00 \mathrm{a}$ \\
\hline & $42,68 \mathrm{~b}$ & $25,19 b$ \\
\hline & $88,50 \mathrm{c}$ & $63,72 \mathrm{~d}$ \\
\hline $\begin{array}{l}\text { konsentrasi Cd } 150 \\
\mathrm{mg} / \mathrm{Kg}\end{array}$ & $142,10 \mathrm{~d}$ & $101,53 \mathrm{f}$ \\
\hline \multicolumn{3}{|c|}{$\begin{array}{c}\text { Keterangan : Angka rata-rata yang diikuti dengan } \\
\text { huruf yang sama menunjukkan tidak } \\
\text { berbeda nyata pada uji BNJ / Tukey taraf } \\
\\
\alpha=5 \% .\end{array}$} \\
\hline
\end{tabular}

Berdasarkan uji statistik metode One Way ANOVA, hasil penelitian menunjukkan bahwa perlakuan pemberian logam kadmium $0 \mathrm{mg} / \mathrm{Kg}$ menghasilkan rata-rata konsentrasi logam pada tanah di media awal dan akhir sebesar $0,00 \mathrm{mg} / \mathrm{Kg}$. Kemudian rata-rata konsentrasi logam pada tanah di media akhir dengan perlakuan pemberian logam kadmium $150 \mathrm{mg} / \mathrm{Kg}$ adalah paling tinggi sebesar 101,53 mg/Kg. Hal ini menunjukkan bahwa semakin tinggi penambahan konsentrasi pencemar logam kadmium dalam media tanah, maka semakin besar pula konsentrasi logam kadmium yang diserap oleh tanaman hanjuang. Menurut Malik dan Biswas (2012), setiap tanaman memiliki kemampuan yang berbeda - beda untuk menyerap logam berat tergantung dari konsentrasi logam di dalam media tersebut. Selain itu, adanya perbedaan konsentrasi menyebabkan terjadinya perpindahan logam berat secara difusi dan osmosis yaitu massa zat pada media dengan konsentrasi tinggi akan berpindah ke media yang konsentrasinya rendah (Haryanti et al, 2012).

\section{Konsentrasi Logam Pada Jaringan Tanaman}

Kemampuan tanaman hanjuang dalam menyerap logam kadmium dapat diketahui dari nilai konsentrasi logam yang diserap oleh bagian tanaman tersebut. Bagian tanaman yang dapat menyerap logam adalah akar, batang, dan daun. Oleh karena itu, dilakukan pengukuran logam berat pada ketiga bagian tanaman tersebut. Nilai konsentrasi logam kadmium pada jaringan akar, batang, dan daun dapat dilihat pada Tabel 2.

Tabel 2. Konsentrasi Logam Kadmium pada Akar, Batang dan Daun

\begin{tabular}{|c|c|c|c|}
\hline Perlakuan & $\begin{array}{c}\text { Akar } \\
(\mathrm{mg} / \mathrm{Kg})\end{array}$ & $\begin{array}{c}\text { Batang } \\
\text { (mg/Kg) }\end{array}$ & $\begin{array}{c}\text { Daun } \\
(\mathrm{mg} / \mathrm{Kg})\end{array}$ \\
\hline $\begin{array}{l}\text { konsentrasi Cd } \\
0 \mathrm{mg} / \mathrm{Kg}\end{array}$ & $0,00 \mathrm{a}$ & 0,00 & 0,00 \\
\hline $\begin{array}{l}\text { konsentrasi Cd } \\
50 \mathrm{mg} / \mathrm{Kg}\end{array}$ & $13,42 \mathrm{~b}$ & 0,00 & 0,00 \\
\hline $\begin{array}{l}\text { konsentrasi Cd } \\
100 \mathrm{mg} / \mathrm{Kg}\end{array}$ & $21,40 \mathrm{~b}$ & 0,00 & 0,00 \\
\hline $\begin{array}{l}\text { konsentrasi Cd } \\
150 \mathrm{mg} / \mathrm{Kg}\end{array}$ & $36,22 \mathrm{c}$ & 0,25 & 0,00 \\
\hline $\begin{aligned} \text { Keterangan } & : \\
& \text { hı } \\
& b c \\
& \alpha\end{aligned}$ & \multicolumn{3}{|c|}{$\begin{array}{l}\text { : Angka rata-rata yang diikuti dengan } \\
\text { huruf yang sama menunjukkan tidak } \\
\text { berbeda nyata pada uji BNJ/Tukey taraf } \\
\alpha=5 \% \text {. }\end{array}$} \\
\hline
\end{tabular}

Tabel 2 menunjukkan penyerapan logam kadmium pada jaringan tanaman (akar, batang, dan daun). Berdasarkan hasil uji statistik metode One Way ANOVA, menunjukkan bahwa rata-rata konsentrasi logam pada akar tanaman dengan perlakuan pemberian logam kadmium paling tinggi terdapat pada konsentrasi $150 \mathrm{mg} / \mathrm{Kg}$ sebesar $36,22 \mathrm{mg} / \mathrm{Kg}$. Sedangkan pada bagian batang maupun daun tanaman tidak ditemukan adanya penyerapan logam kadmium. 
Tingginya konsentrasi logam kadmium di dalam akar dibandingkan dengan di batang dan daun tanaman dapat terjadi karena letak akar yang dekat dengan sedimen, sedangkan batang dan daun jaraknya relatif lebih jauh dari sedimen. Menurut Moenir (2010), mekanisme dan akumulasi logam berat oleh tanaman terbagi pada 3 tahap, yaitu penyerapan logam berat oleh akar, translokasi logam berat dari akar ke bagian tanaman yang lain, dan lokalisasi/akumulasi logam berat oleh bagian organ tanaman. Penelitian yang dilakukan oleh Ulimma et al. (2015) yaitu fitoremediasi logam mekuri $(\mathrm{Hg})$ oleh tanaman hanjuang menunjukkan bahwa konsentrasi logam merkuri $(\mathrm{Hg})$ dari akar menuju daun semakin berkurang konsentrasinya.

\section{Faktor Biokonsentrasi}

Faktor biokonsentrasi dihitung untuk mengetahui kemampuan tanaman dalam mentranslokasikan logam berat. Menurut Baker dalam Sari et al. (2017), tanaman dibagi dalam tiga kategori berdasarkan nilai biokonsentrasi (BCF) yang diperoleh yaitu tanaman sebagai metal accumulator jika memiliki nilai biokonsentrasi (BCF) > 1 , tanaman sebagai metal excluder memiliki nilai biokonsentrasi $(\mathrm{BCF})<1$ dan tanaman sebagai metal indicator dengan nilai biokonsentrasi (BCF) mendekati satu. Selanjutnya Baker dan Brooks (1989) dalam Sari et al. (2017) mengembangkan bahwa tanaman hanjuang tidak termasuk kategori tanaman akumulator karena memiliki nilai biokonsentrasi $(\mathrm{BCF})<1$. Hal tersebut dapat dilihat pada Tabel 3.

Tabel 3. Data Biokonsentrasi

\begin{tabular}{lc}
\hline \multicolumn{1}{c}{ Perlakuan } & Biokonsentrasi \\
\hline $\mathrm{Cd} 0 \mathrm{mg} / \mathrm{Kg}$ & 0 \\
$\mathrm{Cd} 50 \mathrm{mg} / \mathrm{Kg}$ & 0,31 \\
$\mathrm{Cd} 100 \mathrm{mg} / \mathrm{Kg}$ & 0,25 \\
$\mathrm{Cd} 150 \mathrm{mg} / \mathrm{Kg}$ & 0,26 \\
\hline
\end{tabular}

Pada dasarnya faktor biokonsentrasi adalah suatu perhitungan yang dapat digunakan untuk menduga tanaman dapat dijadikan sebagai agen fitoremediasi atau tidak. Berdasarkan Tabel 3, nilai biokonsentrasi $(\mathrm{BCF})$ tanaman hanjuang $<1$ menyatakan bahwa tanaman tersebut termasuk ke dalam metal excluder. Mogopodi et al. (2011) dalam Wahwakhi (2017) menjelaskan bahwa tanaman excluder adalah tanaman yang membatasi pengangkutan logam melalui akarnya yaitu dengan cara mengendapkan logam tersebut dan membatasi masuknya bahan pencemar ke dalam tanaman pada tingkat akar saja.

\section{Efisiensi Penyerapan}

Efisiensi penyerapan logam kadmium oleh tanaman merupakan informasi yang menggambarkan kemampuan tanaman dalam menyerap logam. Efisiensi Penyerapan logam kadmium dapat dilihat pada Tabel 4.

Tabel 4. Efisiensi Penyerapan Logam $\mathrm{Cd}$ oleh Tanaman Hanjuang

\begin{tabular}{lc}
\multicolumn{1}{c}{ Perlakuan } & Efisiensi Penyerapan (\%) \\
\hline $\mathrm{Cd} 0 \mathrm{mg} / \mathrm{Kg}$ & 0 \\
$\mathrm{Cd} 50 \mathrm{mg} / \mathrm{Kg}$ & 31,46 \\
$\mathrm{Cd} 100 \mathrm{mg} / \mathrm{Kg}$ & 24,20 \\
$\mathrm{Cd} 150 \mathrm{mg} / \mathrm{Kg}$ & 25,67 \\
\hline
\end{tabular}

Berdasarkan Tabel 4, efisiensi penyerapan logam kadmium yang paling tinggi terdapat pada konsentrasi $50 \mathrm{mg} / \mathrm{kg}$ sebesar $31,46 \%$. Tingginya efisiensi tanaman hanjuang (Cordyline fruticosa) dikarenakan tanaman tersebut memiliki volume perakaran yang banyak, sehingga akar tanaman tersebut menyebar keseluruh bagian tanah yang telah terkontaminasi logam kadmium (Haryanti et al., 2013). Namun, efisiensi penyerapan menurun dengan bertambahnya konsentrasi Cd yang ditambahkan. Hal ini mungkin terjadi karena kemampuan akar tanaman hanjuang menyerap $\mathrm{Cd}$ sudah mencapai batas maksimum. Perlu dilakukan penelitian lebih lanjut mengenai hal tersebut.

\section{Faktor Transport}

Nilai faktor transport dihitung untuk mengetahui translokasi pencemar logam kadmium yang masuk ke bagian tanaman dari tanah ke akar ataupun ke bagian lain di tanaman (Barman et al., 2000 dalam Irawanto dan Mangkoedihardjo, 2015). Nilai $\mathrm{TF}>1$ menunjukkan bahwa tanaman 
mentranslokasikan pencemar dengan efektif dari tanah ke akar (Baker dan Brooks, 1989 dalam Irawanto dan Mangkoedihardjo, 2015). Nilai faktor transport pada tanaman hanjuang dilihat pada Tabel 5.

Tabel 5. Nilai Faktor Transport

\begin{tabular}{lcc}
\hline \multicolumn{1}{c}{ Perlakuan } & Daun & Batang \\
\hline konsentrasi Cd $0 \mathrm{mg} / \mathrm{Kg}$ & 0,00 & 0,00 \\
konsentrasi Cd $50 \mathrm{mg} / \mathrm{Kg}$ & 0,00 & 0,00 \\
konsentrasi Cd $100 \mathrm{mg} / \mathrm{Kg}$ & 0,00 & 0,00 \\
konsentrasi Cd $150 \mathrm{mg} / \mathrm{Kg}$ & 0,00 & 0,00 \\
\hline
\end{tabular}

Keterangan : Angka rata-rata yang diikuti dengan huruf yang sama menunjukkan tidak berbeda nyata pada uji BNJ / Tukey taraf $\alpha=5 \%$.

Berdasarkan hasil uji statistik metode One Way ANOVA, untuk faktor transport daun dan batang tidak memberikan pengaruh nyata terhadap perlakuan pemberian logam kadmium. Hasil penelitian menunjukkan bahwa tidak ada penyerapan logam pada bagian daun dan batang tanaman sehingga tidak terdapat faktor transport pada tanaman hanjuang.

Menurut Majid et al. (2014) dalam Wahwakhi (2017) kategori faktor transport dibagi menjadi dua, yaitu faktor transport (TF) $>1$ termasuk ke dalam tanaman dengan mekanisme fitoekstraksi dan faktor transport (TF) $<1$ termasuk ke dalam tanaman dengan mekanisme fitostabilisasi. Dari hasil penelitian didapatkan nilai faktor transport (baik daun maupun batang) < 1 yang menunjukkan translokasi logam kadmium lebih besar ke bagian akar tanaman dibandingkan dengan bagian batang atau daun tanaman sehingga mekanisme yang terjadi pada proses penyerapan logam kadmium adalah fitostabilisasi.

\section{Bioakumulasi}

Bioakumulasi logam kadmium menggambarkan jumlah logam yang diserap dan diakumulasi pada jaringan tanaman. Bioakumulasi dihasilkan dari masa 42 hari penanaman. Nilai Bioakumulasi logam kadmium pada jaringan tanaman (akar, batang, dan daun) dapat dilihat pada Tabel 6 .

Berdasarkan hasil uji statistik metode One Way ANOVA, diperoleh hasil bahwa terdapat perbedaan nyata faktor bioakumulasi pada akar dan total tanaman dengan perlakuan pemberian logam kadmium. Sedangkan untuk faktor bioakumulasi pada bagian batang dan daun tanaman tidak terdapat perbedaan nyata dengan perlakuan pemberian logam kadmium. Hasil penelitian menunjukkan bahwa rata-rata bioakumulasi pada akar, batang dan daun (total) dengan perlakuan pemberian logam kadmium yang paling tinggi terdapat pada konsentrasi $150 \mathrm{mg} / \mathrm{Kg}$ sebesar $0,03 \mathrm{mg} / \mathrm{Kg}$.

Tabel 6. Bioakumulasi Logam Kadmium pada Jaringan Tanaman

\begin{tabular}{|c|c|c|c|c|}
\hline Perlakuan & $\begin{array}{c}\text { Akar } \\
\text { (mg) }\end{array}$ & $\begin{array}{l}\text { Batan } \\
\text { g (mg) }\end{array}$ & $\begin{array}{c}\text { Daun } \\
\text { (mg) }\end{array}$ & $\begin{array}{c}\text { Total } \\
\text { (mg/tanam } \\
\text { an) }\end{array}$ \\
\hline $\begin{array}{l}\text { konsentrasi } \\
\mathrm{Cd} 0 \mathrm{mg} / \mathrm{Kg} \\
\text { konsentrasi }\end{array}$ & $0,00 \mathrm{a}$ & 0,00 & 0,00 & $0,00 \mathrm{a}$ \\
\hline $\begin{array}{l}\mathrm{Cd} 50 \\
\mathrm{mg} / \mathrm{Kg} \\
\text { konsentrasi }\end{array}$ & $0,01 \mathrm{a}$ & 0,00 & 0,00 & $0,01 \mathrm{ab}$ \\
\hline $\begin{array}{l}\mathrm{Cd} 100 \\
\mathrm{mg} / \mathrm{Kg} \\
\text { konsentrasi }\end{array}$ & $0,01 \mathrm{a}$ & 0,00 & 0,00 & $0,01 \mathrm{abc}$ \\
\hline $\begin{array}{l}\mathrm{Cd} 150 \\
\mathrm{mg} / \mathrm{Kg}\end{array}$ & $0,03 \mathrm{~b}$ & 0,00 & 0,00 & $0,03 \mathrm{bcd}$ \\
\hline Keterangan & $\begin{array}{l}\text { Angka } \\
\text { Iruf J } \\
\text { rbeda } \\
=5 \%\end{array}$ & $\begin{array}{r}\text { ta-rata } \\
\text { sam }\end{array}$ & $\begin{array}{l}\text { ang d } \\
\text { menun } \\
\text { iij } \mathrm{BNI}\end{array}$ & $\begin{array}{l}\text { iikuti dengan } \\
\text { jukkan tidak } \\
\text { / Tukey taraf }\end{array}$ \\
\hline
\end{tabular}

\section{Potensi Remediasi}

Nilai potensi remediasi logam kadmium pada media tanah dapat dilihat pada Tabel 7 .

Tabel 7. Nilai Efektivitas Penyisihan

\begin{tabular}{lc}
\hline \multicolumn{1}{c}{ Perlakuan } & $\begin{array}{c}\text { Efektivitas Penyisihan } \\
(\%)\end{array}$ \\
\hline konsentrasi Cd $0 \mathrm{mg} / \mathrm{Kg}$ & $0,00 \mathrm{a}$ \\
konsentrasi Cd $50 \mathrm{mg} / \mathrm{Kg}$ & $40,92 \mathrm{bc}$ \\
konsentrasi Cd $100 \mathrm{mg} / \mathrm{Kg}$ & $28,03 \mathrm{~b}$ \\
konsentrasi Cd $150 \mathrm{mg} / \mathrm{Kg}$ & $28,56 \mathrm{~b}$ \\
\hline Keterangan : Angka rata-rata yang diikuti dengan \\
huruf yang sama menunjukkan tidak \\
berbeda nyata pada uji BNJ / Tukey taraf \\
$\alpha=5 \%$.
\end{tabular}

Pada Tabel 7 terlihat bahwa terdapat perbedaan nyata efektivitas penyisihan dengan perlakuan pemberian logam kadmium. Hasil penelitian menunjukkan bahwa rata - rata remediasi dengan perlakuan pemberian logam kadmium konsentrasi 50 $\mathrm{mg} / \mathrm{Kg}$ adalah yang paling tinggi sebesar 
40,92 \%. Perhitungan potensi remediasi dilakukan untuk melihat tingkat keberhasilan tanaman dalam menyerap konsentrasi logam atau efektivitas fitoremediasi dengan pengaruh perbedaan perlakuan. Efektivitas fitoremediasi dapat dilihat besarnya nilai Removal Efectivity (Efektivitas penyisihan) logam berat dalam media (Khoiriyah, 2015 dalam Hotmaria, 2017).

\section{KESIMPULAN}

Akumulasi logam kadmium tertinggi ditemukan pada bagian akar tanaman pada konsentrasi $150 \mathrm{mg} / \mathrm{Kg}$ dengan konsentrasi sebesar 36,22 mg/Kg. Sedangkan pada bagian batang maupun daun tanaman tidak ditemukan adanya penyerapan logam. Efisiensi penyerapan logam kadmium yang paling tinggi terdapat pada konsentrasi 50 $\mathrm{mg} / \mathrm{kg}$ sebesar 31,46\%. Tanaman hanjuang yang terkontaminasi oleh logam kadmium memiliki nilai biokonsentrasi (BCF) $<1$ sehingga termasuk ke dalam kelompok metal excluder. Distribusi logam kadmium lebih tinggi pada bagian akar dengan faktor transport $(\mathrm{TF})<1$ sehingga tanaman hanjuang termasuk ke dalam tanaman fitoremediasi dengan mekanisme penyerapan logamnya yaitu fitostabilisasi.

\section{DAFTAR PUSTAKA}

Badan Standarisasi Nasional. (2004). Air dan limbah-bagian 4:Cara Uji Kadmium (Cd) Secara Destruksi Asam Dengan Spektrofotometri Serapan Atom (SSA) Nyala. SNI 066992.4-2004. Hal 3 - 6.

Dewi, K. S. P. (2010). Tingkat Pencemaran Logam Berat $(\mathrm{Hg}, \mathrm{Pb}, \mathrm{Cd})$ di dalam Sauran, Air Minum dan Rambut di Denpasar, Gianyar dan Tabanan (Skripsi). Universitas Udayana, Bali.

Estuningsih, Pertiwi, Hidayati dan Syarif. (2013). Potensi Tanaman Rumput Sebagai Agen Fitoremediasi Tanah Terkontaminasi Limbah Minyak Bumi. Prosiding Semirata 1: 360 370.
Fardiaz, S. (2008). Polusi Air dan Udara. Yogyakarta: Penerbit Kanisius.

Ghosh, M., and S. P. Singh. (2013). Comparative Uptake and Phytoextraction Study of Soil Induced Chromium by Accumulator and High Biomass Weed Spesies. Journal Applied Ecology and Environmental Research, (3), 67 69

Haque, N., J. R. Peralta-Videa., G. L. Jones., T. E. Gill., and J. L. Gardea Torresdey. (2008). Screening The Phytoremediation Potential of Dessert Broom (Baccharis Sarothroides Gray) Growing on Mine Tailings in Arizona, USA. Environmental Pollution, 153, 362 368.

Haryati, M., Purnomo, T., dan Kuntjoro, S. (2012). Kemampuan Tanaman Genjer (Limnocharis flava (L.)) Buch menyerap logam berat timbal $(\mathrm{Pb})$ limbah cair kertas pada biomassa dan waktu pemaparan yang berbeda. Lentera Bio, (1) 3, $131-138$.

Haryanti, D., D. Budianta., dan Salni. (2013). Potensi Beberapa Jenis Tanaman Hias sebagai Fitoremediasi Logam Timbal $(\mathrm{Pb})$ dalam Tanah. Jurnal Penelitian Sains, 16 (2), 52 58.

Hidayati, N. (2005). Fitoremediasi dan Potensi Tumbuhan Hiperakumulator. Bogor. Pusat Penelitian Biologi LIPI. ISSN 08548587

Hotmaria. (2017). Karakter dan Efektivitas Fitoremediasi Trembesi (Albizia Saman (Jacq.) Merr.) Terinfeksi Fungi Mikoriza Arbuskula Terhadap Timbal Pada Media Kultur Cair (Skripsi). Fakultas Matematika dan Ilmu Pengetahuan Alam Universitas Nusa Bangsa, Bogor.

Indriyana, N. D. (2014). Analisis Biomassa dan Kandungan Karbon Pada Jenis Serasah Daun Tanaman Hutan Kota 
di Arboretum Arsitektur Lanskap IPB (Skripsi). Fakultas Kehutanan Konservasi Sumberdaya Hutan dan Ekowisata IPB, Bogor.

Irawanto, R., dan S. Mangkoedihardjo. (2015). Fitoforensik Logam Berat ( $\mathrm{Pb}$ dan $\mathrm{Cd}$ ) Pada Tumbuhan Akuatik (Acanthus Ilicifolius dan Coix Lacryma-Jobi). Jurnal Purifikasi Surabaya. Lembaga Ilmu Pengetahuan Indonesia, 15 (1), 62 63.

Kadir. (2015). Statistika Terapan: Konsep, Contoh dan Analisis Data dengan Program SPSS/Lisrel dalam Penelitian. Jakarta: PT Rajagrafindo Persada.

Malik, N and Biswas, A. K. (2012). Role of Higher Plants In Remediation of Metal Contaminated Sites. Scientific Reviews \& Chemical Communications, 2 (2), 141-146.

Moenir, M. (2010). Kajian Fitoremediasi sebagai Alternatif Pemulihan Tanah Tercemar Logam Berat. Jurnal Riset Teknologi Pencegahan dan Pencemaran Industri, 1(2), 115 123.

Pratiwi, I. K. (2017). Fitoakumulasi Ion Logam Tembaga (II) Oleh Tanaman Lidah Mertua (Sansevieria trifasciata Prain) (Skripsi). Universitas Hasanuddin, Makassar.

Raskin, I., and B. D. Ensley. (1999). Phytoremediation Of Metals: Using Plants to Clean Up The Environment, Environmental Pollution And Green Plants. ISSN: 978-0-471-19254-1.

Sari, E.M, A. Hanifah., and F. K. Ganis. (2017). Potensi Tanaman Azolla (Azolla pinnata) Sebagai Fitoremediator Ion Timbal (II), Ion Kadmium (II) Dan Ion Kromium (II). Jurnal. Fakultas Matematika dan Ilmu Pengetahuan Universitas Riau, Riau.
Sarma, H. (2011). Metal Hyperaccumulation in Plants: A Review Focusing on Phytoremediation Technology. Journal of Environmental Science and Technology, 4 (2), 118 - 138. Asian Network for Scientific Information.

Udiharto, M., dan Sudaryono. (1992). Bioremediasi Terhadap Tanah Tercemar Minyak Bumi Parafinik dan Aspak. Prosiding Seminar Nasional Teknologi Pengelolaan Limbah dan Pemulihan Kerusakan Lingkungan (BPPT hal 121 - 132). Jakarta.

Ulimma, R., I. Apriani., dan S. Siahaan. 2015. Potensi Tanaman Hias Dalam Meremediasi Tanah Tercemar Logam Merkuri (Hg) (Skripsi). Universitas Tanjungpura, Pontianak.

Wahwakhi, S. (2017). Potensi Acanthus ilicifolius Sebagai Agen Fitoremediasi dan Fitomining Pada Logam $\mathrm{Cu}$ di Kelurahan Wonorejo Kota Surabaya (Thesis). Institut Pertanian Bogor.

Widowati, W., A. Sastiana., and J. Raymond. (2008). Efek Toksik Logam Pencegahan dan Penanggulangan Pencemaran. Yogyakarta: Penerbit Andi.

Wulandari, Resmaya, T. Purnomo., dan Winarsih. (2014). Kemampuan Tanaman Kangkung Air (Ipomoea aquatic) dalam Menyerap Logam Berat Kadmium (Cd) Berdasarkan Konsentrasi dan Waktu Pemaparan yang Berbeda. Lentera Bio 3 (1), 83 $-89$.

Yusuf, M. (2014). Fitoremediasi Tanah Tercemar Logam Berat $\mathrm{Pb}$ dan $\mathrm{Cd}$ Dengan Menggunakan Tanaman Lidah Mertua (Sansevieria trifasciata) (Skripsi). Program Studi Teknik Lingkungan Jurusan Sipil Fakultas Teknik Universitas Hasanuddin, Makassar. 